\title{
Effect of Four Antioxidants Combination on Number of Sertoli and Leydig Cells, Sperm Quality and Caspase-3 Expression in Rat Exposed to Cigarette Smoke
}

\author{
Conita Yuniarifa ${ }^{1}$, Joko Wahyu Wibowo ${ }^{2}$, Taufiqurrachman Nasihun ${ }^{3}$ \\ ${ }^{1}$ Master Program of Biomedical Sciences, Faculty of Medicine, Sultan Agung Islamic University \\ ${ }^{2}$ Department of Nutrition, Faculty of Medicine, Sultan Agung Islamic University \\ ${ }^{3}$ Department of Biochemistry, Faculty of Medicine, Sultan Agung Islamic University \\ *corresponding author: conitayuniarifa@gmail.com
}

\begin{abstract}
Introduction: The administration of antioxidant combination has been shown to be more effective than that of individual antioxidant in male infertility. Objective: to determine the effect of different combination of antioxidants (vitamin/vit $C$, vit $E$, glutathione and zinc) on the number of Sertoli and Leydig cells, sperm quality and texpression of caspase-3 in rats exposed to cigarette smoke.

Methods: This was an experimental study using a post test only control group design. Thirty six rats were randomly divided into 6 groups to receive one of the following combinations of antioxidants: vit $C$ and E, glutathione, zinc (T4-G); vit C and E, glutathione (T3-G); vit C and vit E (T2-G); Glutathione, zinc (T1-G); control positive (CP-G) cigarette smoke exposed only, normal (CN-G). The dose of vit $C$, vit E, glutathion and zinc was $9 \mathrm{mg} /$ day, $1.8 \mathrm{IU} / \mathrm{day}$, $1.8 \mathrm{mg} /$ day, $0.2 \mathrm{mg} /$ day respectively. All groups were exposed to cigarette smoke (3 cigarettes/day for 21 days), except for the CN-G group. On day 22, sperm samples were taken. Testicular tissue was taken for measurements of sperm quality, sertoli and leydig cell.numbers.

Results: There was a significant difference in mean number of Leydig cells, sperm motility, sperm count and caspase-3 between groups ( $p<0.05)$. Post hoc LSD showed that the administration of combination of four antioxidant agent increasing the number of Sertoli cells and sperm morphology. The results also showed that group treated with 4 antioxidants combination had the highest number of Leydig cells, sperm motility, sperm counts and the lowest expression of caspase-3.

Conclusion:The combination of vitC, vit E, glutathione and zinc affects the number of Sertoli and Leydig cells, sperm quality, expression of caspase-3 in rats exposed to cigarette smoke.
\end{abstract}

Keywords: Sertoli and Leydig cells, sperm quality, expression of caspase-3

\begin{abstract}
ABSTRAK
Pendahuluan: Pemberian kombinasi antioksidan lebih efektif daripada pemberian antioksidan tunggal pada infertilitas pria. Tujuan: Mengetahui perbedaan efek pemberian kombinasi vitamin C, vitamin E, glutation, dan zink terhadap jumlah sel Sertoli, jumlah sel Leydig, kualitas sperma dan ekspresi caspase-3 pada tikus yang dipapar asap rokok.

Metode: Penelitian ini menggunakan metode eksperimental dengan post test only control group design. Subyek berjumlah 36 ekor tikus dibagi secara acak menjadi 6 kelompok: Kelompok kombinasi vitamin C, vitamin E, glutation, dan zink (T4-G); kelompok kombinasi vitamin C, vitamin E, dan glutation (T3-G); kelompok kombinasi vitamin C dan vitamin E (T2-G); kelompok kombinasi glutation dan zink (T1-G); kelompok kontrol positif (CP-G); dan kelompok kontrol normal (CN-G). Dosis vitamin C 9 mg/hari, vitamin E 1,8 $\mathrm{IU} /$ hari, glutation $1,8 \mathrm{mg} /$ hari dan zink $0,2 \mathrm{mg} /$ hari. Semua kelompok diberi paparan asap rokok 3 batang/hari selama 21 hari, kecuali kelompok CN-G. Pengambilan sperma dan pembedahan testis dilakukan pada akhir penelitian (hari ke 22).

Hasil: Hasil uji sel Leydig, motilitas, jumlah sperma dan caspase-3 menunjukkan perbedaan signifikan $(p<0,05)$. Uji post hoc LSD menunjukkan pemberian kombinasi 4 antioksidan mempunyai jumlah sel Sertoli dan morfologi sperma paling banyak. Hasil uji juga menunjukkan kombinasi 4 antioksidan memiliki jumlah sel Leydig, motilitas, jumlah sperma paling tinggi dan menunjukkan ekspresi caspase-3 paling rendah.

Kesimpulan: Kombinasi vitamin C, vitamin E, glutation dan zink berpengaruh terhadap jumlah sel Sertoli, jumlah sel Leydig, kualitas sperma, ekspresi caspase-3 pada tikus yang dipapar asap rokok.
\end{abstract}

Kata kunci : sel Sertoli, sel Leydig, kualitas sperma, ekspresi caspase-3.

\section{INTRODUCTION}

Thirty to eighty percents of male infertility are associated with oxidative stress through damage in testicular cells such as Leydig cells and Sertoli cells, whose playing a role in steroidogenesis and spermatogenesis, respectively. To deal with oxidative stress, various antioxidants have been used, such as vitamin (Vit) C, Vit E, zinc, glutathione, and other antioxidants either alone or in combination. However, there has been no conclusive findings. A study conducted by Kusumo

Copyright @ 2020 Authors. This is an open access article distributed under the terms of the Creative Commons Attribution-NonCommercialShareAlike 4.0 International License (http://creativecommons.org/licenses/by-nc-sa/4.0/), which permits unrestricted non-commercial use, distribution, and reproduction in any medium, provided the original author and source are properly cited. 
Yuniarifa, et al.

(2014) showed that the administration of vit $C$ and zinc itself or in combination increases sperm count in BALB/c, compared to control group (Kusumo, 2014). A study stated that the administration of glutathione to adult male mice increased the progressive sperm motility (Kardi, 2015). Further research is needed to evaluate whether antioxidant combination of vit E, C, glutathione and zinc, is effective against oxidative stress occurred in spermatogonia, spermatocyte, spermatids, sperm, Sertoli cells, and Leydig cells, which are very susceptible to oxidative stress. Studies have shown that cigarette smoke causes oxidative stress on the testes, therefore in this study cigarette smoke exposure was used to trigger oxidative stress (Kardi, 2015).

Cigarette smoke contains gasses and particles having potential to cause free radicals (Kardi, 2015), thus causing infertility in men. Various substances in cigarette smoke form free radicals, entering the blood stream, then spreading throughout the body including the genital organs and cause oxidative stress in testes and decrease in sperm count (Maggini, Beveridge and Suter, 2012).

In addition, a cigarette smoke also causes damage to Leydig cells, Sertoli cells and sperm leading to alteration in sperm morphology and motility. Various free radical compounds in the testes are resulted from binding of cigarette smoke to cell membrane lipids, deoxyribonucleic acid (DNA), and proteins, leading to the alteration in the structure function and apoptosis. Apoptosis occurs when DNA damage can not be corrected by the DNA repair mechanism. In apoptosis, caspase-3 is an important protein serving as the enzyme executor (Johnson, 2011).

The objective of this study was to determine the effect of different antioxidant combinations on sperm quality, Leydig cells, Sertoli cell count, and caspase-3 activity.

\section{METHODS}

This research was a laboratory experimental study with a post-test only control group design approach using white male Wistar rats. Thirty six rats aged 8 months, weighing 150-200 grams were employed. In this study, the objects were randomly divided into 6 groups consisting of the normal control group $(\mathrm{CN}-\mathrm{G})$; positive control group (CP-G); the combination group of vitamin C, vitamin E, glutathione, and zinc (T4-G); the combination group of vitamin $C$, vitamin $E$, and glutathione (T3-G); group combination of vitamin $C$ and vitamin E (T2-G); and the combination group of glutathione and zinc (T1-G). The control positive group (CP-G) was only exposed to cigarette smoke, while the CN-G was not expossed to cigarette smoke nor administered with any antioxidants. The dose of vitamin C, E, glutathione and zinc was $9 \mathrm{mg} /$ day, $1.8 \mathrm{IU} /$ day, $1.8 \mathrm{mg} /$ day, $0.2 \mathrm{mg} /$ day respectively. All groups were exposed to cigarette smoke 3 cigarettes/ day except for the normal group. The study was conducted for 21 days because the combination of vit $C$ and $E$ has been shown to increase sperm concentration, motility and morphology and lower level of 8-hydroxy-2-deoxyguanosine (8-OhdG) semen within 21 days (Sutanto, 2016). During the study, the rats were fed with a commercial pellet (AD II, Japfa Comfeed Ltd., Indonesia), and was allowed to drink mineral water adlibitum. On day 22 , sperm sample was obtained and testicular surgery was conducted. This research was conducted after obtaining approval from the ethics committee of the Faculty of Medicine UNISSULA Semarang (No.365/XI/2017/Bioethics Commission).

\section{Sertoli Cells}

Sertoli cell count as the average number of Sertoli cells, obtained from rat testes stained with haematoxylin and eosin (H\&E). It was calculated at 5 fields of view under light microscope at 40x10 magnification. The base layer of Sertoli cells attached to the basement membrane and extending towards the tubular lumen. It has oval cell nucleus, and has more than one nucleolus with one part eosinophilic and/or the other basophilic part (Johnson, 2011).

\section{Leydig Cells}

Leydig cell count as the average number of Leydig cells, obtained from rat testes stained with Haematoxylin-eosin. It was calculated at 5 fields of view under light microscope at 40x10 magnification. Leydig cells are polyhedral epithelioid cells with a single round nucleus and an acidophilic cytoplasm containing granules (Johnson, 2011).

\section{Sperm Quality Assay}

Sperm quality assay was carried out based on sperm motility, count, and morphology as described as follows:

\section{Sperm Motility}

Sperm motility is the percentage of number of motile sperm obtained for every 200 sperm in 5 field of view, calculated according to World Health Organisation (World Health Organization, 2010):

PR + NP $\times 100 \%$

200 
http://jurnal.unissula.ac.id/index.php/sainsmedika

Effect of Four Antioxidants Combination on Number of Sertoli and Leydig Cells, Sperm Quality and Caspase-3 Expression ...

$\mathrm{PR}=$ Progressive motility (sperm move actively, either in a linear direction or in a large circle, regardless of speed)

$\mathrm{NP}=$ non-progressive motility (sperm moves but is not progressive, for example swimming in a small circle, the sperm's tail moves but cannot push the head, or only the tail of the sperm appears to be moving).

\section{Sperm Count}

Assesment of the sperm count was done by well-stirring semen diluted with a leukocyte pipette with George's solution (100 $\mathrm{ml} \mathrm{3 \%}$ sodium citrate, 1

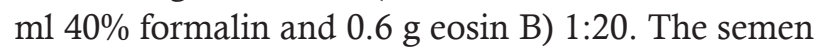
sample was transferred to a standard hemocytometer, Neubauer's counting room which has been closed using a closed glass for 15-20 minutes so that all cells settle. The sperm count (n) was counted in the count room area of $1 \mathrm{~mm} \mathrm{2}$, under a light microscope at 400 times magnificantion. The sperm count (million/mL) was calculated using the formula:

n x 20 × 104 (World Health Organization, 2010).

\section{Sperm Morphology}

The sperm morphology was assessed by calculating the percentage number of sperm with normal form. The percentage obtained by calculating from 200 sperm in accordance with the form under a light microscope using at 400 times magnification. The morphology assessment immediately after the dry semen smear was fixed and stained in order to see the sperm in detail using Papanicolaou stain. The stained samples viewed under a microscope shows that the head of sperm in the region of pale blue and dark blue the post accrosomal region, at the center of the reddish while the tail is blue or red (World Health Organization, 2010). Morphologically, normal sperm have several criteria: an oval head shape with a smooth shape line, and the length of the head about 4-5 $\mu \mathrm{m}$ in wide and 2.5-3 $\mu \mathrm{m}$. The total length and width ratio should be 1.5-1.75. In addition, it should have a welldefined acrosome region comprising $40 \%-70 \%$ of the head area. The tail should be straight, uniform, uncoiled and about $45 \mu \mathrm{m}$ in length (Gatimel et al., 2017).

\section{Caspase-3 expression}

The expression of caspase- 3 was evaluated from the percentage of positive cells expressing caspase- 3 on immunohistochemical (IHC) staining. Cells are considered positive to express caspase- 3 when brown color appears in the cytoplasm and nucleus. The cell is negative when it appears blue or purple in the cytoplasm and nucleus. Measurement used method of calculating a Hot Spot in 5 field of viewunder a light microscope at magnification of 40x10 and expressed in mean (AlDissi et al., 2010).

\section{Statistical analysis}

There were some test applied in this study. For the normality finding, Shapiro-Wilk was applied. In addition, for the homogeneity finding, Levene test was applied in this study. The data on the number of Sertoli cells and the sperm morphology had a normal and homogeneous distribution, then analyzed using one-way ANOVA test. Data on Leydig cell count, sperm motility, sperm count and caspase- 3 results were abnormal and/or not homogeneous. Thus, the Kruskal Wallis test was performed. The significance of this study was considered valid if the $p<0.05$.

\section{RESULTS}

After exposed by cigarette smoke and administered with antioxidant combination for 21 days, the number of Sertoli cells and Leydig cells, sperm quality and the expression of caspase- 3 in male wistar rats as indicated on the Table 1.

The statistical analysis was conducted to determine significant difference in mean number of Sertoli cell and sperm morphology between groups. Since there were no significant difference between groups ( $p>0.05)$, and considering the results of Shapiro Wilk test and the Levene test, one-way ANOVA test was performed. Significant difference between groups $(p<0.05)$ was found in ANOVA test analysis.

The results of Shapiro Wilk and Levene Test's of mean number of Leydig cells, sperm count and sperm morphology, and caspase- 3 showed a significant difference $(\mathrm{p}<0.05)$, Kruskal Wallis was then performed. Significant differences between groups $(p=0.001)$ were found. To determine which groups having a significant differerence, Post Hoc test on Sertoli cell number and morphology of sperm, as well as Mann whitney to the number and motility of sperm, and caspase- 3 as are as follows:

\section{Number of Sertoli Cells}

The Post Hoc test of Sertoli Cells average number in the T4-G, T3-G, T2-G, T1-G, and CN-G groups were significantly higher than that of CP-G group $(p<0.05)$. In contrary, the mean number of Sertoli cells in T1-G, T2-G, and T3-G was significantly lower than that of T4-G $(p<0.05)$. The data also showed that the mean number of Sertoli cells in T2-G was significantly lower 
Yuniarifa, et al.

Table 1. Mean number of Sertoli and Leydig cells, sperm quality (motility, sperm count, and morphology) and the expression of caspase- 3 in every group

\begin{tabular}{|c|c|c|c|c|c|c|c|}
\hline \multirow{3}{*}{ Variable } & \multicolumn{6}{|c|}{ Group } & \multirow{3}{*}{$p$-value } \\
\hline & $\begin{array}{l}\text { CN-G } \\
(n=6)\end{array}$ & $\begin{array}{l}\text { CP-G } \\
(n=6)\end{array}$ & $\begin{array}{l}\text { T4-G } \\
(n=6)\end{array}$ & $\begin{array}{l}\text { T3-G } \\
(n=6)\end{array}$ & $\begin{array}{l}\text { T2-G } \\
(n=6)\end{array}$ & $\begin{array}{l}\text { T1-G } \\
(n=6)\end{array}$ & \\
\hline & $\chi \pm S D$ & $\chi \pm$ SD & $\chi \pm S D$ & $\chi \pm S D$ & $\chi \pm S D$ & $\chi \pm$ SD & \\
\hline \multirow[t]{2}{*}{ Number of SertoliCells $(\Sigma)$} & 26.60 & 6.13 & 23.83 & 18.60 & 10.87 & 13.50 & \multirow{2}{*}{$0.001^{*}$} \\
\hline & $\pm 1, .6$ & \pm 0.74 & \pm 0.71 & \pm 0.42 & \pm 0.85 & \pm 1.03 & \\
\hline \multirow[t]{2}{*}{ Number of LeydigCells $(\Sigma)$} & 28.20 & 5.63 & 23.00 & 16.70 & 10.57 & 13.40 & \multirow{2}{*}{$0.001^{\wedge}$} \\
\hline & \pm 6.47 & \pm 0.56 & \pm 0.51 & \pm 1.74 & \pm 0.83 & \pm 1.04 & \\
\hline \multirow[t]{2}{*}{ Sperm Motility (\%) } & 65.16 & 26.43 & 64.00 & 58.76 & 32.03 & 54.57 & \multirow{2}{*}{$0.001^{\wedge}$} \\
\hline & \pm 0.56 & \pm 0.87 & \pm 0.51 & \pm 1.02 & \pm 0.94 & \pm 2.13 & \\
\hline \multirow[t]{2}{*}{ Sperm count (\%) } & 46.22 & 18.09 & 44.93 & 41.63 & 19.88 & 36.90 & \multirow{2}{*}{$0.001^{\wedge}$} \\
\hline & \pm 0.65 & \pm 0.39 & \pm 0.82 & \pm 1.50 & \pm 0.72 & \pm 0.77 & \\
\hline \multirow[t]{2}{*}{ Sperm Morphology (\%) } & 38.09 & 21.47 & 37.12 & 34.49 & 25.71 & 31.45 & \multirow{2}{*}{$0.001^{*}$} \\
\hline & \pm 0.62 & \pm 0.64 & \pm 0.55 & \pm 0.99 & \pm 0.96 & \pm 1.23 & \\
\hline \multirow[t]{2}{*}{ Caspase3Expression (\%) } & 1.23 & 8.23 & 2.30 & 4.33 & 5.53 & 5.63 & \multirow{2}{*}{$0.001^{\wedge}$} \\
\hline & \pm 1.15 & \pm 0.61 & \pm 0.28 & \pm 0.55 & \pm 0.24 & \pm 0.20 & \\
\hline
\end{tabular}

Note: $*=$ One-Way Anova test, ${ }^{\wedge}=$ Kruskal Wallis Test

than that of $\mathrm{T} 1-\mathrm{G}$ and $\mathrm{T} 3-\mathrm{G}(\mathrm{p}<0.05)$. It was regarded as the similar findings of the mean number of Sertoli cell in T4-G in which it was significantly lower than that of $\mathrm{CN}-\mathrm{G}(\mathrm{p}<0.05)$. See the Figure 1,2 to know the details of the amounts of Sertoli Cells.

The finding of the study defined that all groups which administered with antioxidant combination had an effect on the number of Sertoli cells. The highest numbers of Sertoli cells were found in the group treated with combination of vitamin $C$, vitamin $E$, glutathione, and zinc (T4-G), followed by T3-G, T1-G, and T2-G.

\section{Number of Leydig Cells}

Mann Whitney test results showed that the number of Leydig cells in the T4-G, T3-G, T2-G, T1$\mathrm{G}$, and $\mathrm{CN}-\mathrm{G}$ group was significantly higher than that of the CP-G group $(p<0.05)$. Meanwhile, the number of Leydig cells in T1-G, T2-G, and T3-G was significantly lower than that of T4-G $(p<0.05)$. The same result also found in the number of Leydig cells in which T2-G was significantly lower than that of T1-G and T3-G (p $<0.05$ ). Likewise, the number of Leydig cells in T4-G was lower than that of $\mathrm{CN}-\mathrm{G}(\mathrm{p}<0.05)$ (Fig. $1 \& 2$ )

Comparing with the normal group, all groups administered with antioxidant combination had higher number of Leydig cells. The group treated with the combination of vitamin $\mathrm{C}$ and $\mathrm{E}$, glutathione, zinc (T4$\mathrm{G})$ seemed to have the highest number of Leydig cells. The range of the highest number of Leydig cells can be seen in T4-G followed by T3-G, T1-G, T2-G.

\section{Sperm count}

The mean number of sperm count in T4-G, T3G, T2-G, T1-G, and CN-G groups was significantly higher than that of CP-G group $(p<0.05)$ based on the Mann Whitney test results. The number of sperm in T4-G ( $p<0.05)$ was significantly higher than that of T1-G, T2-G, and T3-G. Furthermore, the number of sperm count in T2-G was significantly lower than that of T1-G and T3-G ( $p<0.05)$. Likewise, the number of sperm count in T4-G was significantly lower than that of $\mathrm{CN}-\mathrm{G},(\mathrm{p}<0.05)$ (Figure 3A). All antioxidant combination showed higher number of sperm count. The highest number of sperm count was found in the group treated with a combination of vitamin $C$, vitamin $\mathrm{E}$, glutathione, and zinc (T4-G) followed by T3-G, T1$\mathrm{G}$, and $\mathrm{T} 2-\mathrm{G}$.

\section{Sperm Motility}

The sperm motility in the T4-G, T3-G, T2-G, T1-G, and CN-G groups was significantly higher than that of CP-G group $(p<0.05)$ based on Mann Whitney test results. The sperm motility in T1-G, T2-G, and T3$G$ was significantly lower than that of T4-G $(p<0.05)$. In addition, the motility of the sperms in T2-G was significantly lower than that of T1-G and T3-G (p $<0.05$ ). Likewise when compared between T4-G and $\mathrm{CN}-\mathrm{G}, \mathrm{p}<0.05$ (Figure 3B ). The groups administered with antioxidant combination had higher motility than negative control group. The group treated with the combination of vit $C$, vit $E$, glutathione and zinc (T4-G) 
http://jurnal.unissula.ac.id/index.php/sainsmedika

Effect of Four Antioxidants Combination on Number of Sertoli and Leydig Cells, Sperm Quality and Caspase-3 Expression ...
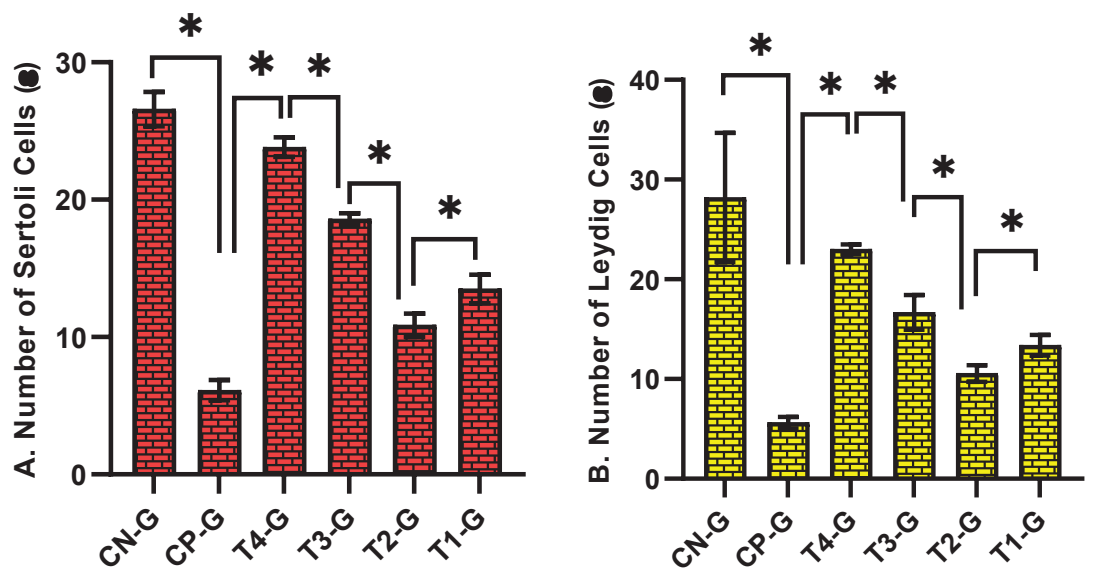

Figure 1. A. Number of Sertoli Cells. B. Number of Leydig Cells in each group. Post Hoc analysis: * $p<0.05$
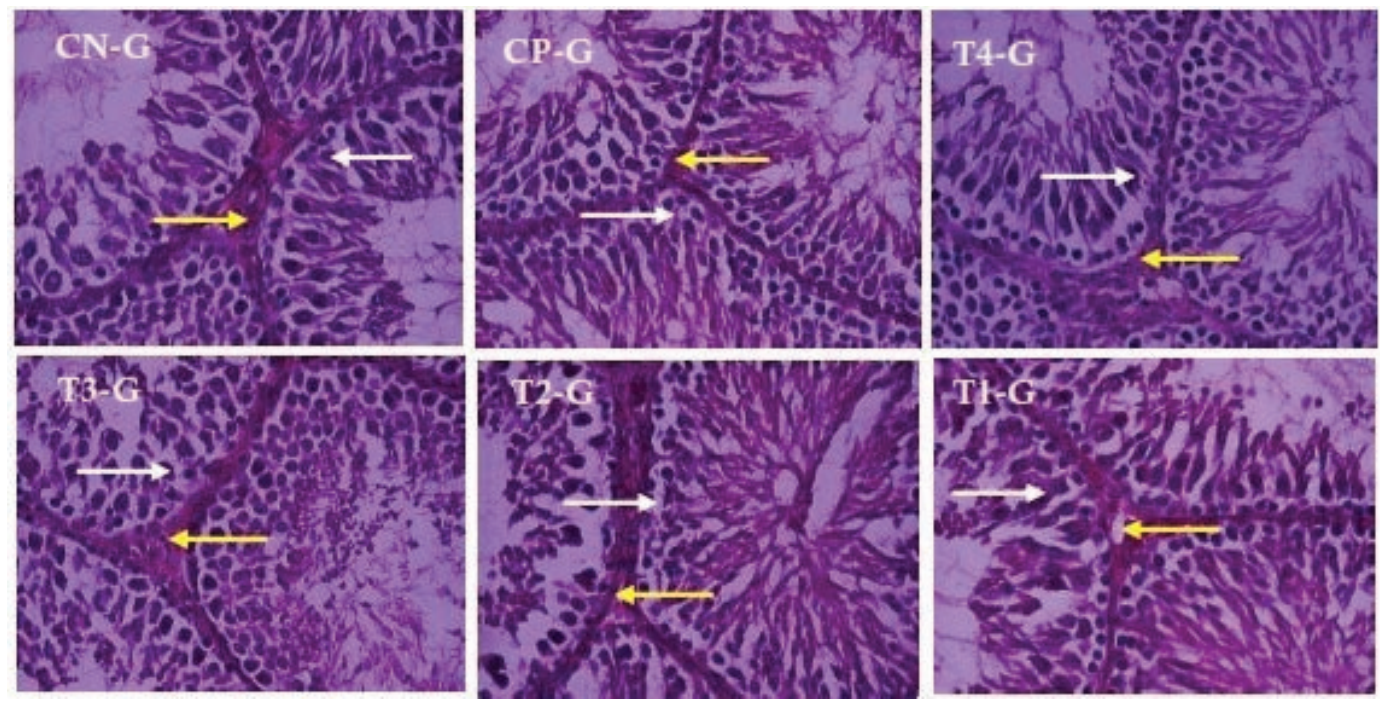

Figure 2. histological preparation of testis was stained with hematoxilin eosin in each group.: Sertoli and Leydig cells

followed by T3-G, T1-G, and T2-G has been considered as the group whivh has the highest sperm motility.

\section{Sperm Morphology}

Based on the results of the Post Hoc test, it can be concluded that the number of morphologically normal sperm in the T4-G, T3-G, T2-G, T1-G, and $\mathrm{CN}-\mathrm{G}$ groups was significantly higher than that of CP-G group $(p<0.05)$. Different with the number of morphologically normal sperm in T1-G, T2-G, and T3$G$, the study found that it was significantly lower than of T4-G ( $p<0.05)$. The number of morphologically normal spermazoa in T2-G was significantly lower than that of T1-G and T3-G ( $p<0.05)$. Likewise, T4-G was significantly lower than of CN-G $(p<0.05)$ (Figure $3 C)$. The groups administered with antioxidant combination had better number of sperm morphology than negative control group. Again, the group which treated with the combination of vit $\mathrm{C}$, vit $\mathrm{E}$, glutathione and zinc (T4$\mathrm{G})$ had the highest number of morphologically normal sperm followed by T3-G, T1-G, and T2-G .

\section{Caspase-3 expression}

The results of Caspase-3 expression was identified by the Mann Whitney test. It has been showed that caspase-3 expression in the T4-G, T3G, T2-G, T1-G, and CN-G groups was significantly lower than that of CP-G group ( $p<0.05)$. The number of caspase-3 expressions in T1-G, T2-G, and T3-G was significantly higher than that of T4-G ( $p<0.05)$. The number of caspase- 3 expressions in T2-G and T1-G was significantly higher than that of T3-G ( $p$ $<0.05)$. It can be stated that there was no significant difference between T2-G and T1-G, (p>0.05). Similar 
Yuniarifa, et al.
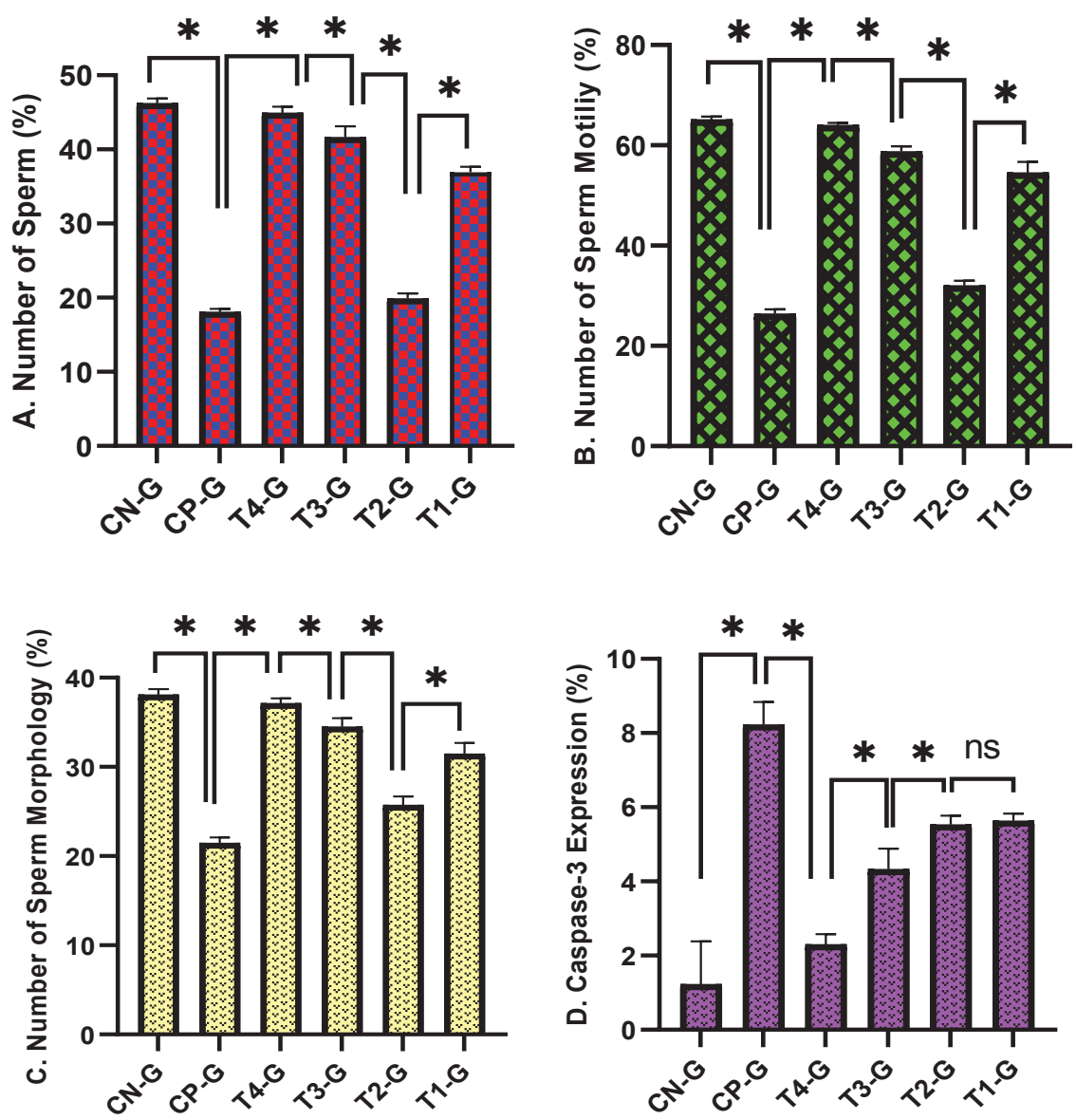

Figure 3. A. Number of sperm; B. Number of sperm motility; C. Number of sperm morphology; and D. Number of Caspase-3 Expression in each group. Post Hoc analysis: * $\mathrm{p}<0.05$; ns: not significant

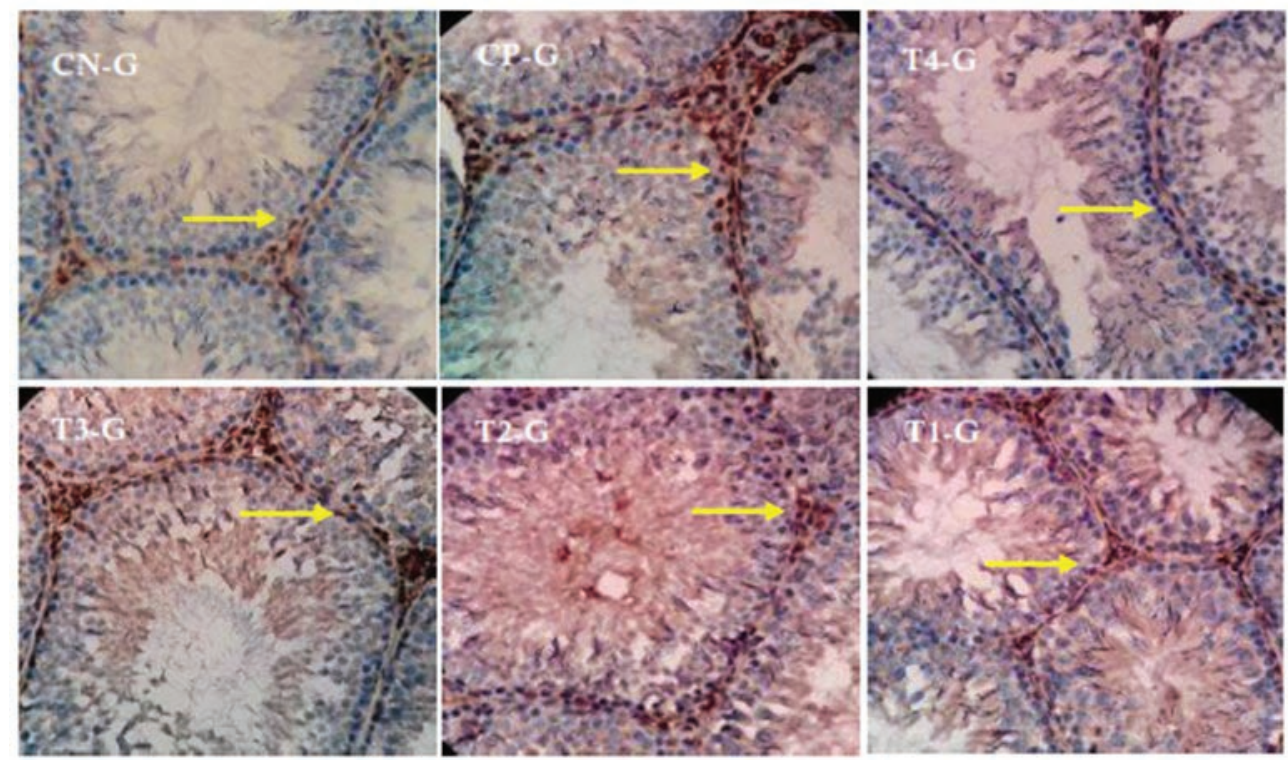

Figure 4. Histological preparation of caspase-3 expression in each group following treatment

to the previous statement, there were also no significant difference in caspase-3 expressions between T4-G and $C N-G(p>0.05)$. Figure $3 D, 4$ gave the detailed information about the Caspase- 3 expression. This shows that the expression of caspase- 3 in T4-G is equivalent to normal. The groups administered with antioxidant combination and normal group had a lower caspase3 expression compared to positive control group. The 
http://jurnal.unissula.ac.id/index.php/sainsmedika

Effect of Four Antioxidants Combination on Number of Sertoli and Leydig Cells, Sperm Quality and Caspase-3 Expression ...

lowest caspase-3 expression was found in the group treated with the combination of vitamin $C$, vitamin $\mathrm{E}$, glutathione, and zinc (T4-G) followed by T3-G, T1-G, and T2-G.

\section{DISCUSSION}

There were some results related to this study. First, the findings of the study indicated that rats without the exposure to smoke has higher number of Sertoli and Leydig cells, motility sperm, sperm count, and morphologically normal sperm and the lower caspase-3 expression compared to the group exposed to cigarette smoke. It has been proved that cigarette smoke decreases the number of Leydig and Sertoli cells, and sperm. Moreover, the cigarrette smoke also give the bad effects to the shape and motility of sperm. The exposure to free radicals from cigarette smoke causes oxidative stress. Studies have shown that cigarette smoke does not only reduce levels of antioxidants circulating in the blood, but also increase prooxidants or free radicals (Berg, Gaag and Hendriks, 2002; Hansen et al., 2013). The compounds in free radicals produced by cigarette smoke bind to DNA, proteins and membrane lipids. They also lead to the change in the function and structure of cells. The apoptosis mediated cell death can be happened as the result of this change. Apoptosis due to exposure to cigarette smoke can take place via an intrinsic pathway, that is triggered by an increase in reactive oxygen species (ROS) and DNA damage. DNA damage causes increased activity of p53, cytochrome C, caspase-9, and caspase-3 as executors (Chowdhury, Tharakan and Bhat, 2006). Therefore, apoptosis due to cigarette smoke exposure, caspase-3 is an important protein that can be used as an indicator (Johnson, 2011).

The findings of this study confirmed that the combination of four antioxidants, consists of vit $\mathrm{C}$, vit $\mathrm{E}$, glutathione, and zinc improve the damage of testicular cell, including Sertoli cells and Leydic cells. Vitamin C is able to scavenge hydroxyl free radicals. In addition, vitamin $\mathrm{E}$ also acts as a scavenger of free radicals entering the body, and soluble in a fat medium such as cell membranes (Sankako et al., 2012). This finding supports a research by Kusumo (2014) showing that the administration of vitamin $\mathrm{C}$, zinc alone or in combination can increase sperm count in BALB/c mice compared to positive control (group by exposure to cigarette smoke) by $53.5 \%, 47.7 \%$ and $55.5 \%$ respectively (Kusumo, 2014). Similiarly, Kardi's research also showed that the increasing progressive sperm motility can be achieved by administration of glutathione in adult male mice exposed to cigarette smoke (Kardi, 2015).

The combination of four antioxidants reduces caspase-3 expression compared to other different combinations in rats which were exposed to the smoke of cigarette. It indicates that the treatment reduce apoptosis. The combination of four antioxidants is able to ameliorate the damage, cell death, DNA mutation, replication errors, and genomic instability. This is in accordance with the research of (Soetrisno K, 2016) showing that Aloe vera extract, which contains various antioxidants, can reduce caspase-3 expression and the number of sunburn cells in the epidermis of rats exposed to UVB rays.

Due to the fact that people can be exposed to free radicals everyday, especially from cigarrete smoke, antioxidant suplement is important to protect sperm from the harmful effects of ROS. Vitamin C, E, glutathione, and zinc have the ability to repair sperm cytoplasmic enzymes, which function as endogenous repair and defense mechanisms (Eroschenko, 2011). This finding is in line with study showing that combination of vitamin $\mathrm{C}$ and $\mathrm{E}$ can increase the concentration, motility and morphologically normal sperm and reduce the level of 8-OhdG of semen (Sutanto, 2016).

\section{CONCLUSION}

The administration of vitamin $\mathrm{C}$, vitamin $\mathrm{E}$, glutathione and zinc combination improve the number of Sertoli cells, the number of Leydig cells, the quality of sperm and the expression of caspase- 3 in white male wistar rats exposed to cigarette smoke.

\section{CONFLICT OF INTEREST}

There is no conflict of interest in this publication

\section{ACKNOWLEDGMENT}

We highly appreciate and thank the laboratory staffs of the Center for Food and Nutrition Studies, Gadjah Mada University for their hard work and guidance in maintaining and testing samples during this research.

\section{REFERENCES}

Al-Dissi, A. N. et al. (2010) 'Immunohistochemical expression of vascular endothelial growth factor and vascular endothelial growth factor receptor- 2 in canine simple mammary gland adenocarcinomas', Canadian Veterinary Journal, 51(10), pp. 1109-1114.

Berg, H. van den, Gaag, M. van der and Hendriks, 


\section{Yuniarifa, et al.}

H. (2002) 'Influence of lifestyle on vitamin bioavailability', International Journal for Vitamin and Nutrition Research, 72(1), pp. 53-59. doi: 10.1024/0300-9831.72.1.53.

Chowdhury, I., Tharakan, B. and Bhat, G. K. (2006) 'Current concepts in apoptosis: The physiological suicide program revisited', Cellular and Molecular Biology Letters, 11(4), pp. 506-525. doi: 10.2478/s11658-006-0041-3.

Eroschenko, V. P. (2011) Atlas Histologi di Fiore. 9th edn. Jakarta: EGC.

Gatimel, N. et al. (2017) 'Sperm morphology: assessment, pathophysiology, clinical relevance, and state of the art in 2017', Andrology, 5(5), pp. 845-862. doi: 10.1111/andr.12389.

Hansen, R. D. et al. (2013) 'Effects of smoking and antioxidant micronutrients on risk of colorectal cancer', Clinical Gastroenterology and Hepatology, 11(4), pp. 406-415. doi: 10.1016/ j.cgh.2012.10.039.

Johnson, K. E. (2011) Quick Review Histologi dan Biologi Sel. Textbook. Tangerang Selatan: Binarupa Aksara Publisher.

Kardi (2015) Pemberian Glutation pada Mencit Jantan Dewasa yang Terpapar Asap Rokok dapat Meningkatkan Motilitas Progresif Sperm. Universitas Udayana. http://jurnal.unissula.ac.id/index.php/sainsmedika

Kusumo, M. S. G. (2014) Pengaruh Pemberian Vitamin C dan Zinc terhadap Jumlah Sperma Mencit Balb/c yang Terpapar Asap Rokok. Universitas Muhammadiyah Surakarta.

Maggini, S., Beveridge, S. and Suter, M. (2012) 'A Combination of High-dose Vitamin C Plus Zinc for the Common Cold', J Agric Food Chem, 40(1), pp. 28-42. doi: 10.1177/147323001204 000104

Sankako, M. K. et al. (2012) 'Possible mechanism by which zinc protects the testicular function of rats exposed to cigarette smoke', Pharmacological Reports, pp. 1537-1546. doi: 10.1016/S17341140(12)70951-9.

Soetrisno K (2016) Pengaruh Ekstrak Aloe Vera terhadap Penurunan Ekspresi Caspase-3 dan Jumlah Sunburn Cell pada Epidermis. Universitas Islam Sultan Agung.

Sutanto, E. B. (2016) Pengaruh Kombinasi Vitamin C dan Vitamin E terhadap Kualitas Sperma dan Kadar 8-OhdG Semen Tikus pada Tikus (Rattus norvegicus) Jantan Galur Wistar yang Dipapar Asap Rokok. Universitas Islam Sultan Agung.

World Health Organization (2010) WHO Laboratory Manual for the Examination and Processing of Human Semen. 5th edn. Geneva: World Health Organization. 